\title{
Effects of high and normal soyprotein breakfasts on satiety and subsequent energy intake, including amino acid and 'satiety' hormone responses.
}

Citation for published version (APA):

Veldhorst, M. A. B., Nieuwenhuizen, A. G., Hochstenbach-Waelen, A., Westerterp, K. R., Engelen, M. P., Brummer, R. J., Deutz, N. E., \& Westerterp-Plantenga, M. S. (2009). Effects of high and normal soyprotein breakfasts on satiety and subsequent energy intake, including amino acid and 'satiety' hormone responses. European Journal of Nutrition, 48(2), 92-100. https://doi.org/10.1007/s00394-0080767-y

Document status and date:

Published: 01/01/2009

DOI:

10.1007/s00394-008-0767-y

Document Version:

Publisher's PDF, also known as Version of record

Document license:

Taverne

Please check the document version of this publication:

- A submitted manuscript is the version of the article upon submission and before peer-review. There can be important differences between the submitted version and the official published version of record.

People interested in the research are advised to contact the author for the final version of the publication, or visit the DOI to the publisher's website.

- The final author version and the galley proof are versions of the publication after peer review.

- The final published version features the final layout of the paper including the volume, issue and page numbers.

Link to publication

\footnotetext{
General rights rights.

- You may freely distribute the URL identifying the publication in the public portal. please follow below link for the End User Agreement:

www.umlib.nl/taverne-license

Take down policy

If you believe that this document breaches copyright please contact us at:

repository@maastrichtuniversity.nl

providing details and we will investigate your claim.
}

Copyright and moral rights for the publications made accessible in the public portal are retained by the authors and/or other copyright owners and it is a condition of accessing publications that users recognise and abide by the legal requirements associated with these

- Users may download and print one copy of any publication from the public portal for the purpose of private study or research.

- You may not further distribute the material or use it for any profit-making activity or commercial gain

If the publication is distributed under the terms of Article $25 f a$ of the Dutch Copyright Act, indicated by the "Taverne" license above, 
Margriet A.B. Veldhorst

Arie G. Nieuwenhuizen

Ananda Hochstenbach-Waelen

Klaas R. Westerterp

Marielle P.K.J. Engelen

Robert-Jan M. Brummer

Nicolaas E.P. Deutz

Margriet S. Westerterp-Plantenga

\section{Effects of high and normal soyprotein breakfasts on satiety and subsequent energy intake, including amino acid and 'satiety' hormone responses}

Received: 22 May 2008

Accepted: 1 December 2008

Published online: 13 January 2009

M.A.B. Veldhorst ( $\square)$

A.G. Nieuwenhuizen

A. Hochstenbach-Waelen

K.R. Westerterp

M.S. Westerterp-Plantenga

Dept. of Human Biology

Nutrition and Toxicology Research

Institute (NUTRIM)

Maastricht University, P.O. Box 616

6200 MD Maastricht, The Netherlands

Tel.: +31-43/388-4596

Fax: +31-43/367-0976

E-Mail: m.veldhorst@hb.unimaas.nl

M.A.B. Veldhorst · A.G. Nieuwenhuizen

A. Hochstenbach-Waelen

K.R. Westerterp - R.-J.M. Brummer

N.E.P. Deutz - M.S. Westerterp-Plantenga

Top Institute Food and Nutrition

Wageningen, The Netherlands

M.P.K.J. Engelen · N.E.P. Deutz

Dept. of Surgery

Nutrition and Toxicology Research

Institute (NUTRIM)

Maastricht University

Maastricht, The Netherlands
Abstract Background The role of dietary protein in short term satiety is of interest with respect to body weight regulation. Aim To compare the effects of a high versus a normal soyprotein breakfast on satiety and subsequent energy intake (EI), including 'satiety' hormones and plasma amino acid responses. Methods Twenty-five healthy subjects (mean \pm SEM, BMI: $23.9 \pm 0.3 \mathrm{~kg} / \mathrm{m}^{2}$; age: $22 \pm 1$ years) received a subjectspecific standardized breakfast: a custard with soy as single protein type with either 10/55/35 (normalprotein) or 25/55/20 (high-protein) En\% protein/carbohydrate/ fat in a randomized, single-blind design. Appetite profile (Visual Analogue Scale, VAS), plasma glucose, insulin, Glucagon-like Peptide 1, ghrelin, and amino acid concentrations were determined for $4 \mathrm{~h}$, determining the sensitive time point to assess EI. Since at 180 min glucose and insulin concentrations still were significantly different, in a second set of experiments subjects received an ad lib lunch at 180 min after the breakfasts; EI was assessed. Results Overall the $25 \mathrm{En} \%$ soy-custard was rated as being more satiating than the $10 \mathrm{En} \%$ soy-custard $(P<0.01)$ and there was a difference at $20 \mathrm{~min}$ after breakfast ( $64 \pm 5$ vs. $52 \pm 5$ mmVAS, $P<0.05$ ), related to higher postprandial taurine concentrations $(P<0.05)$. Insulin response was increased more after the $25 \mathrm{En} \%$ than after the $10 \mathrm{En} \%$ soy-custard (AUC: 7,520 \pm 929 vs. $4,936 \pm 468 \mathrm{mU} / \mathrm{l} \mathrm{h}, P<0.001)$. There was no difference in EI (25 En\%: $3,212 \pm 280 \mathrm{~kJ}$ vs. $10 \mathrm{En} \%$ : $3,098 \pm 286 \mathrm{~kJ}, \mathrm{~ns})$. Conclusion A high soyprotein breakfast is more satiating than a normal soyprotein breakfast related to elevated taurine and insulin concentrations.

Key words satiety energy intake - soyprotein taurine - insulin

\section{Introduction}

The increasing incidence of obesity is considered as a major health problem due to its co-morbidity of a
2, cardiovascular disease, and certain types of cancer $[14,15]$. Obesity is the result of a positive energy balance due to energy intake (EI) exceeding energy expenditure. In the system of body weight regulation several pathways are involved and therefore weight management requires a multi-factorial approach [29]. 
Recent findings suggest that a relatively elevated protein intake seems to play a role during weight loss as well as during weight maintenance thereafter $[4,12$, 17, 28]. The importance of satiety in this respect appears from the study by Weigle et al. [28] where a high protein diet reduced ad lib food intake while sustaining satiety at a comfortable level during a 12 -week period. In addition to the protein-induced satiety after a high protein diet, protein-induced satiety has also been shown after a single meal $[3,5$, 7]. Previous studies have shown satiating effects of high versus normal protein meals with a mixture of habitually consumed proteins $[7,29]$. Data on specific proteins in different concentrations affecting satiety are however limited and the question remains whether the larger satiating effects of high protein meals hold for each specific type of protein.

Soyprotein is considered as a complete protein. Its nutritional value is roughly equivalent to that of animal protein of high biological value [33]. A number of studies in animals and humans suggest that consumption of soyprotein has beneficial effects on lipid metabolism and obesity. Several lines of evidence show that soyprotein may favorably affect lipid absorption, insulin resistance, fatty acid metabolism and other hormonal, cellular, or molecular changes associated with adiposity. Soyprotein has also been suggested to decrease EI through increased satiety [27].

In order to answer the question whether the larger satiating effect of high protein meals also holds for soyprotein, we investigated possible differences in satiety between a high and normal amount of soyprotein and the mechanisms accompanying those differences. Since the timing of a test meal plays an important role [2], first the sensitive moment in time to offer a test meal was determined. Soyprotein was offered as a single protein source in a breakfast consisting of $20 \%$ of the subject-specific daily energy requirements, with amounts of soyprotein that represent the highest recommended protein intake per day, i.e. $25 \%$ of energy from protein versus the lowest (normal) protein intake per day, $10 \%$ of energy from protein [18]. Protein was exchanged with fat; carbohydrate content was kept constant at a level of $55 \mathrm{En} \%$ because of its effects on protein metabolism [13].

The aim of the study was to compare the effects of a high versus a normal amount of soyprotein containing breakfast on satiety and EI, including plasma amino acids (AA), glucose, insulin, Glucagon-like Peptide 1 (GLP-1) and ghrelin concentrations over a 4-h period. After having determined the sensitive moment in time, subjects received in a second set of experiments the same breakfasts and ad lib EI at lunch was determined at this time point.

\section{Subjects and methods}

\section{Subjects}

Thirty healthy male and female volunteers [Body Mass Index (BMI) $22-30 \mathrm{~kg} / \mathrm{m}^{2}$, age $18-40$ years] were recruited by advertisements in local newspapers and on notice boards at the university. They underwent a screening including medical history, measurement of body weight and height and cognitive restrained eating using a Dutch translation of the Three Factor Eating Questionnaire (TFEQ) [22, 30]. Twenty-five subjects (11 males, 14 females) were selected on being in good health, non-smokers, non-vegetarian, not cognitively dietary restraint (TFEQ Factor 1 score $\leq 9$ ), not using medication apart from oral contraceptives and at most moderate alcohol users ( $\leq 10$ alcoholic consumptions per week). Their mean age was $22 \pm 1$ year, and their body weight was $74.4 \pm 1.8 \mathrm{~kg}$ (BMI: $23.9 \pm 0.3 \mathrm{~kg} / \mathrm{m}^{2}$ ). A written informed consent was obtained from these participants and the study protocol was approved by the Medical Ethical Committee of the Academic Hospital Maastricht.

\section{Study design}

A randomized, single blind, within-subject experimental study was performed. All subjects came to the university on two occasions, separated by at least 1 week. On each test day subjects received a subjectspecific standardized breakfast and appetite ratings and blood parameters were obtained for $4 \mathrm{~h}$ after breakfast.

The sensitive moment in time to offer lunch was determined by the latest time point after breakfast where (part of) the measured parameters still were statistically significant. After 2 months, when the sensitive moment in time was determined, subjects again came to the university on two occasions in a randomized, single blind design, separated by at least 1 week. On each test day subjects received a subjectspecific standardized breakfast and an ad lib lunch was offered at the pre-determined time point.

\section{Breakfast}

Breakfast was offered as a custard with soy (Supro ${ }^{\circledR}$ 590, The Solae Company, St. Louis, USA) as a single protein source, with either protein/carbohydrate/fat: 10/55/35 En\% (normal protein) or protein/carbohydrate/fat: 25/55/20 En\% (high protein). The breakfast contained $20 \%$ of daily energy requirements, calculated as basal metabolic rate (BMR), according to the equations of Harris-Benedict, multiplied by an activity index of 1.75 which is the average value reported 
Table 1 Amino acid content of the breakfasts given as a custard with either $10 \mathrm{En} \%$ or $25 \mathrm{En} \%$ soyprotein content (g amino acids/100 g custard)

\begin{tabular}{lll} 
& \multirow{2}{*}{ Soy } & \\
\cline { 2 - 3 } & $10 \%$ & $25 \%$ \\
\hline Glutamic acid $^{\mathrm{a}}$ & 0.328 & 0.816 \\
Aspartic acid $^{\mathrm{b}}$ & 0.200 & 0.497 \\
Cysteine & 0.022 & 0.054 \\
Serine & 0.089 & 0.220 \\
Histidine & 0.048 & 0.119 \\
Glycine & 0.071 & 0.177 \\
Threonine & 0.066 & 0.164 \\
Arginine & 0.139 & 0.345 \\
Alanine & 0.073 & 0.182 \\
Tyrosine & 0.069 & 0.171 \\
Valine & 0.085 & 0.212 \\
Methionine & 0.022 & 0.056 \\
Isoleucine & 0.089 & 0.222 \\
Phenylalanine & 0.094 & 0.234 \\
Tryptophan & 0.023 & 0.057 \\
Leucine & 0.145 & 0.360 \\
Lysine & 0.110 & 0.274 \\
Proline & 0.087 & 0.216 \\
\hline
\end{tabular}

${ }^{\mathrm{a}}$ Glutamic acid $=$ glutamine + glutamate

${ }^{\mathrm{b}}$ Aspartic acid $=$ asparagine

for the general population in the Netherlands $[8,31]$. The mean energy content of the breakfast was $2.52 \pm 0.07 \mathrm{~mJ}$ and the provided breakfasts were completely finished within $15 \mathrm{~min}$.

The custards were produced by NIZO Food Research bv. (Ede, The Netherlands) and had tapioca starch (Farinex VA50T, AVEBE, Veendam, The Netherlands and Perfectamyl 3108 AVEBE, Veendam, The Netherlands) and sunflower oil (Reddy, NV Vandemoortele, Roosendaal, The Netherlands) as the carbohydrate and fat sources and were citrus-vanilla (Citrus, J.B. de lange, Belfeld, The Netherlands; Vanilla, J.B. de lange, Belfeld, The Netherlands) flavored. Extensive product development and use of a taste panel lead to custards that did not differ significantly in color, taste, or viscosity. The amino acid composition of the custards is presented in Table 1.

\section{Lunch}

According to a normal Dutch lunch consisting of bread and a filling, lunch consisted of Turkish bread (400 g) with egg salad (400 g) with 13/41/46 En\% protein/carbohydrate/fat with an energy density of $11.4 \mathrm{~kJ} / \mathrm{g}$. Beforehand it was tested whether all subjects liked the lunch sufficiently. Subjects were instructed to eat till they were comfortably full.

\section{Study protocol}

The protocol started at $08.00 \mathrm{~h}$ after an overnight fast from $22.00 \mathrm{~h}$. A Venflon catheter was placed in a superficial dorsal vein of the hand for blood sampling. To obtain arterialized venous blood samples the hand was placed in a thermostatically controlled hot box at $60^{\circ} \mathrm{C}$ for $20 \mathrm{~min}$ before the sampling time. A basal blood sample was taken and appetite ratings were scored. After 5 min a second basal blood sample was obtained and breakfast was offered $(t=0 \mathrm{~min})$ and completed within $20 \mathrm{~min}$. After the first and the last bite, taste perception was scored. Appetite ratings were completed just before breakfast and at 20, 40,60, $80,100,120,180$ and 240 min after breakfast.

Blood samples for urea and amino acid determination were obtained at $-5 \mathrm{~min}$ and subsequently at the same time points as the appetite ratings; blood samples for determination of glucose, insulin, and ghrelin concentrations were obtained before and 40, 60,120 and $180 \mathrm{~min}$ after breakfast. Venous blood samples for determination of GLP-1 concentration were obtained separately before, and at 30,60, 90, 120 and $180 \mathrm{~min}$ after breakfast by means of a Venflon catheter placed in an antecubital vein [1]. Subjects were allowed to drink two glasses of water spread over the morning.

In the second set of experiments, the protocol started after an overnight fast from $22.00 \mathrm{~h}$ at $8.30 \mathrm{~h}$ with scoring appetite ratings. Breakfast was offered $(t=0 \mathrm{~min})$ and completed within $20 \mathrm{~min}$. Lunch was offered at the pre-determined time point of $180 \mathrm{~min}$ after breakfast (see "Results"). Subjects were allowed to drink three glasses of water spread over the entire test period.

\section{Measurements}

\section{Appetite profile}

To determine the appetite profile, hunger, fullness, satiety, and desire to eat were rated on $100 \mathrm{~mm}$ Visual Analogue Scales (VAS), anchored with 'not at all' and 'extremely' during the test day [21]. Subjects were instructed to rate themselves by marking the scale at the point that was most appropriate to their feeling at that time. The distance from this point to the left end of the scale was measured in $\mathrm{mm}$; changes from baseline $(\Delta)$ were calculated by subtracting the baseline score $(-5 \mathrm{~min})$ from the score at a certain time point.

\section{Taste perception}

Taste perception profiles of the custards were assessed after the first and the last bite of the breakfast using $100 \mathrm{mmVAS}$, anchored with 'not at all' and 'extremely' on the aspects: pleasantness, sweetness, sourness, saltiness, bitterness, savouriness, crispiness and creaminess. 


\section{Energy intake}

Lunch was weighed before and after eating and EI was calculated by multiplying the difference of the weight of the lunch by the energy value of the lunch as determined by the product labels $(11.4 \mathrm{~kJ} / \mathrm{g})$.

\section{Blood parameters}

Blood was distributed into EDTA tubes for glucose, insulin, and ghrelin measurement. For GLP-1 measurement blood was collected in EDTA tubes with added dipeptidyl peptidase IV inhibitor. For amino acid and urea determination, blood was collected in lithium heparin tubes. Blood samples were centrifuged at $4^{\circ} \mathrm{C}$ for $10 \mathrm{~min}$ at 3,000 rpm. Hydrochloric acid and phenylmethylsulfonyl fluoride were added to plasma for active ghrelin determination. For amino acid analysis, $250 \mu \mathrm{l}$ plasma was deproteinized by mixing it with $20 \mathrm{mg}$ dry sulfosalicylic acid. For analysis of urea, $200 \mu \mathrm{l}$ plasma was deproteinized by mixing it with $20 \mu \mathrm{l}$ of a $500 \mathrm{~g} / \mathrm{l}$ trichloroacetic acid solution. All samples were stored at $-80^{\circ} \mathrm{C}$ until further analysis. Plasma glucose concentrations were determined using the hexokinase method (Glucose HK 125 kit, ABX diagnostics, Montpellier, France). Insulin concentrations were measured by RIA (Linco Research Inc., St. Charles, Missouri, USA). Plasma active ghrelin concentrations were measured by ELISA (Linco Research Inc., St. Charles, Missouri, USA). Plasma active GLP-1 samples were analyzed using ELISA (EGLP-35K; Linco Research Inc., St. Charles, Missouri, USA). Plasma concentrations of amino acids were determined with the use of a fully automated HPLC (Pharmacia, Woerden, The Netherlands), after precolumn derivatization with $o$ phthaldialdehyde [25]. Plasma urea was analyzed spectrophotometrically on a COBAS Mira S (Roche Diagnostica, Hoffman-La Roche, Basel, Switzerland).

\section{Statistical analysis}

Data are presented as mean changes from baseline \pm standard error to the mean (SEM), unless otherwise indicated [16]. The area under the curve (AUC) of changes from baseline over time was calculated using the trapezoidal method. A repeated measures ANOVA was carried out to test for the effects of protein content and time and a protein content $\times$ time interaction effect on changes in satiety ratings and concentrations of glucose, insulin, ghrelin, GLP-1 and taurine over time. Furthermore, differences between the breakfasts were analyzed per time point. A repeated measures ANOVA was carried out to test for the effect of protein content on the AUC of satiety ratings and concentrations of glucose, insulin, ghrelin, GLP-1, amino acids and urea.
Regression analyses were performed to determine the relationships between the AUC of appetite ratings and the AUC of plasma glucose, insulin, ghrelin, and amino acid responses. Furthermore, regression analyses between the AUC of plasma glucose, insulin, and ghrelin and the AUC of plasma amino acids were performed.

After the second set of experiments, a repeated measures ANOVA was carried out to determine possible differences in EI between the breakfasts. A $P$-value $<0.05$ was regarded as statistically significant. Statistical procedures were performed using StatView 5.0 (SAS Institute Inc., USA, 1998).

\section{Results}

\section{Appetite profile}

Baseline satiety ratings were not different between treatments. There was no protein content $\times$ time interaction effect (ns). Protein content $(P<0.01)$ and time $(P<0.001)$, however, both had an effect on satiety ratings (Fig. 1). Satiety ratings were more increased after a breakfast with $25 \%$ of energy from soyprotein than after a breakfast with $10 \%$ of energy from soyprotein $(P<0.01)$ and there were significant differences over time $(P<0.001$, Fig. 1$)$.

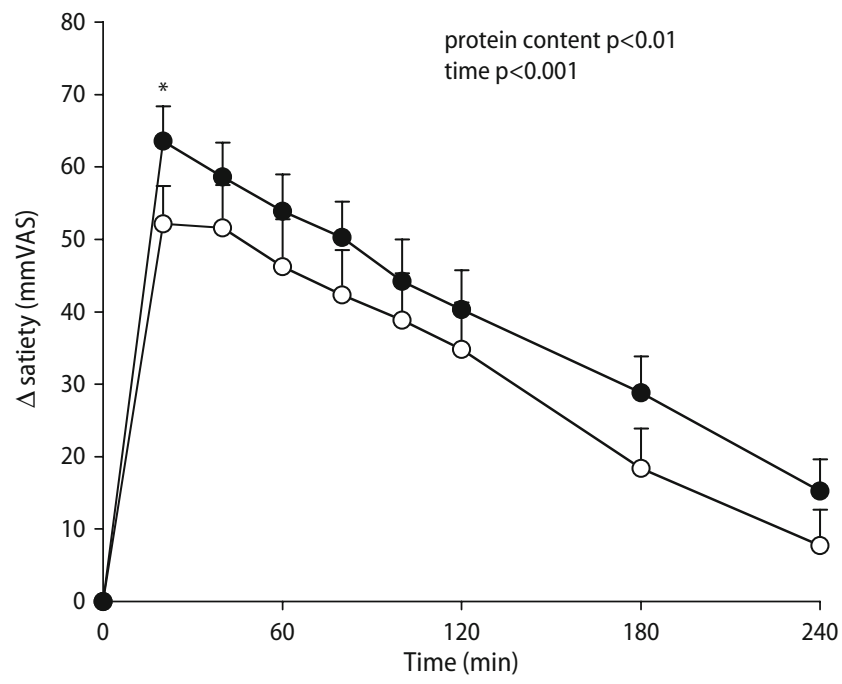

Fig. 1 Changes in satiety (mmVAS) after a soy breakfast given as a custard with either $10 \mathrm{En} \%$ or $25 \mathrm{En} \%$ from protein expressed as delta compared to baseline in 25 subjects (men and women). Values are mean values + SEM. Open circle $10 \%$ of energy from soyprotein, filled circle $25 \%$ of energy from soyprotein. ANOVA repeated measures showed an effect of protein content $(P<0.01)$ and time $(P<0.001)$ on satiety ratings; analysis per time point showed a difference in satiety at 20 min after breakfast $\left({ }^{*} P<0.05\right)$ 
Analysis per time point revealed that after a breakfast with $25 \%$ of energy from soyprotein satiety ratings were more increased than after a breakfast with $10 \%$ of energy from soyprotein at $20 \mathrm{~min}(64 \pm 5$ vs. $52 \pm 5$ mmVAS, $P<0.05$, Fig. 1$)$.

\section{Taste perception}

Pleasantness of taste scores were $53 \pm 5$ and $54 \pm 4$ mmVAS for the breakfast with 10 and $25 \%$ of energy from protein, respectively (ns).

\section{Glucose}

Baseline plasma glucose concentrations were not different between treatments. There was a protein content $\times$ time interaction effect on glucose concentrations $(P<0.05)$, peak values were higher after a breakfast with $10 \%$ of energy from soyprotein whereas glucose concentrations stayed more increased at 120 and 180 min after a breakfast with $25 \%$ of energy from soyprotein (Fig. 2). Glucose concentrations were different over time $(P<0.001$, Fig. 2$)$.

Analysis per time point revealed that glucose concentration was more increased after a breakfast with $25 \%$ of energy from soy than after a breakfast with $10 \%$ of energy from soy at $180 \mathrm{~min}(P<0.05$, Fig. 2).

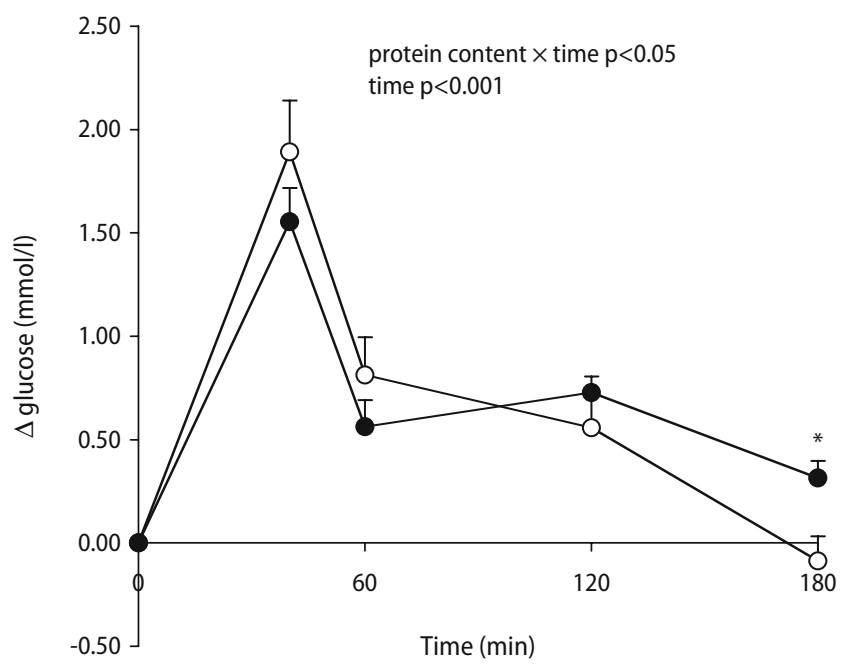

Fig. 2 Changes in glucose concentrations $(\mathrm{mmol} / \mathrm{l})$ after a soy breakfast given as a custard with either $10 \mathrm{En} \%$ or $25 \mathrm{En} \%$ from protein expressed as delta compared to baseline in 25 subjects (men and women). Values are mean values + SEM. Open circle 10\% of energy from soyprotein, filled circle $25 \%$ of energy from soyprotein. ANOVA repeated measures showed a protein content $\times$ time interaction effect $(P<0.05)$ and an effect of time $(P<0.001)$ on glucose concentrations; analysis per time point showed a difference in glucose concentrations at $180 \mathrm{~min}\left({ }^{*} P<0.05\right)$

\section{Insulin}

Baseline plasma insulin concentrations were not different between treatments. The insulin response expressed as AUC was more increased after a breakfast with $25 \%$ of energy from soyprotein than after a breakfast with $10 \%$ of energy from soyprotein $(7,520 \pm 929$ vs. $4,936 \pm 468 \mathrm{mU} / \mathrm{l} \mathrm{h}, P<0.01)$.

There was no protein content $\times$ time interaction effect (ns), whereas protein content $(P<0.001)$ and time $(P<0.001)$ both had an effect on insulin concentrations (Fig. 3). Insulin concentrations were more increased after a breakfast with $25 \%$ of energy from protein than after a breakfast with $10 \%$ of energy from protein $(P<0.001)$ and there were differences over time $(P<0.001$, Fig. 3$)$.

Analysis per time point revealed that insulin concentrations were more increased after a breakfast with $25 \%$ of energy from soy than after a breakfast with $10 \%$ of energy from soy at 60,120 , and $180 \mathrm{~min}$ $(P<0.01, P<0.001$ and $P<0.01$ respectively, Fig. 3$)$.

\section{Ghrelin and GLP-1}

Baseline plasma ghrelin and GLP-1 concentrations were not different between treatments. There was no protein content $\times$ time interaction effect or effect of protein content on ghrelin and GLP-1 concentrations (ns), only time had an effect on ghrelin $(P<0.001)$ or

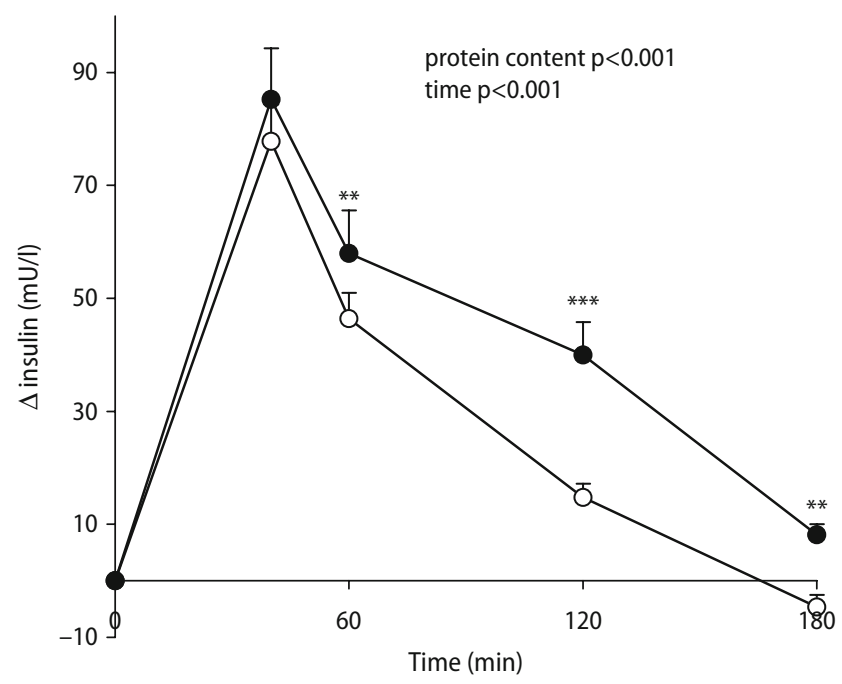

Fig. 3 Changes in insulin concentrations $(\mathrm{mU} / \mathrm{l})$ after a soy breakfast given as a custard with either $10 \mathrm{En} \%$ or $25 \mathrm{En} \%$ from protein expressed as delta compared to baseline in 25 subjects (men and women). Values are mean values + SEM. Open circle $10 \%$ of energy from soyprotein, filled circle $25 \%$ of energy from soyprotein. ANOVA repeated measures showed an effect of protein content $(P<0.001)$ and time $(P<0.001)$ on insulin concentrations; analysis per time point showed a difference in insulin concentrations at $60\left({ }^{* *} P<0.01\right)$ $120\left({ }^{* *} P<0.001\right)$ and $180 \mathrm{~min}\left({ }^{* *} P<0.01\right)$ 


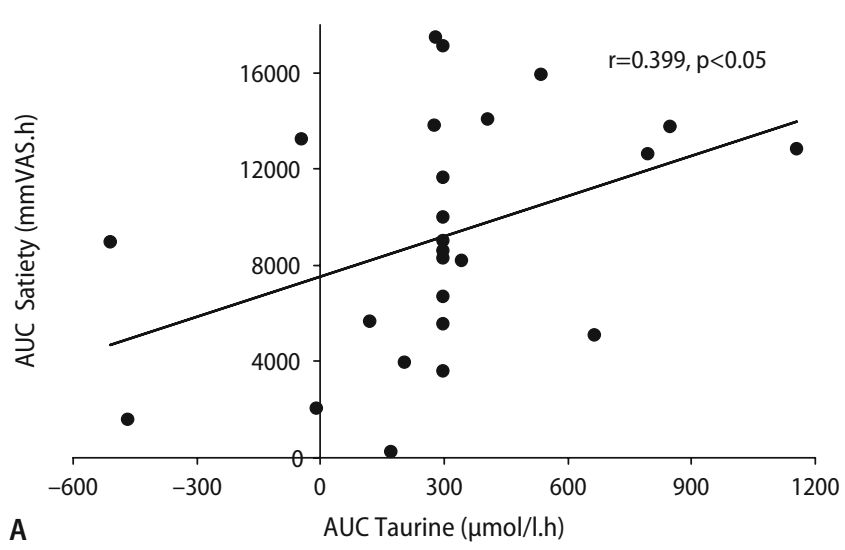

Fig. 4 Relation between satiety responses (mmVAS/h) and taurine responses $(\mu \mathrm{mol} / \mathrm{l} \mathrm{h}, \mathbf{a})$ and hunger responses (mmVAS/h) and taurine responses ( $\mu \mathrm{mol} /$ I h, b) after a breakfast with $25 \%$ of energy from soyprotein in 25 subjects

GLP-1 concentration $(P<0.001)$. Analysis per time point revealed that there were no differences in ghrelin or GLP-1 concentrations between a breakfast with $25 \%$ of energy from soyprotein and a breakfast with $10 \%$ of energy from soyprotein (data not shown).

\section{Correlations}

The AUC of satiety and hunger scores after the breakfast with $25 \%$ of energy from soy were a function of the AUC of the amino acid taurine (satiety: $r=$ $0.399, P<0.05$; hunger: $r=-0.433, P<0.05$, Fig. 4 ).

\section{Amino acids and urea}

Baseline plasma amino acid and urea concentrations were not different between treatments. The AUC of the response of glutamic acid, asparagine, serine, glutamine, histidine, glycine, threonine, citrulline, arginine, alanine, taurine, alpha-aminobutyric acid, tyrosine, valine, methionine, isoleucine, phenylalanine, tryptophan, leucine, ornithine, lysine, branchedchain amino acids (BCAA), sum amino acids (sum AA), and urea are presented in Table 2; significant differences between treatments are indicated. The AUC of nearly all amino acids was more increased after the breakfast with $25 \%$ of energy from protein than after the breakfast with $10 \%$ of energy from $(P<0.05$, Table 2$)$.

The changes in taurine concentrations over time are shown in Fig. 5. There was a protein content $\times$ time interaction effect on taurine concentrations $(P<0.001)$ and an effect of time on taurine concentrations $(P<0.001$, Fig. 5$)$. Analysis per time point revealed that taurine concentrations were more

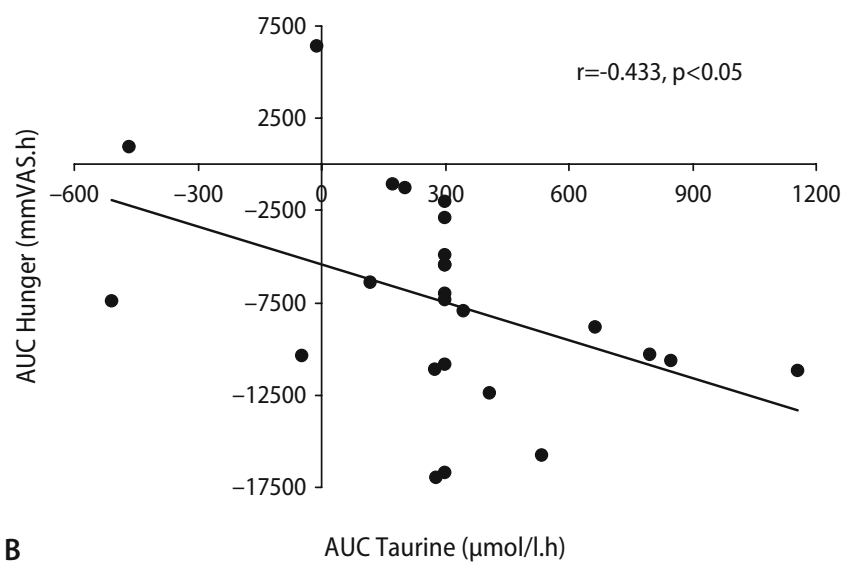

(men and women). The AUC of satiety was a function of the AUC of taurine $(r=0.399, P<0.05)$ and the AUC of hunger was also a function of the AUC of taurine $(r=-0.433, P<0.05)$

Table 2 AUC of amino acid ( $\mu \mathrm{mol} / / \cdot \mathrm{h})$ and urea $(\mathrm{mmol} / \mathrm{l} \cdot \mathrm{h})$ responses after a soyprotein breakfast given as a custard with either $10 \mathrm{En} \%$ or $25 \mathrm{En} \%$ from protein in 25 subjects (men and women)

\begin{tabular}{lcc}
\hline & \multicolumn{2}{l}{ Soy } \\
\cline { 2 - 3 } & $10 \%$ & $25 \%$ \\
\hline Glutamate & $209 \pm 534$ & $3,264 \pm 643^{* * *}$ \\
Asparagine & $5,684 \pm 238$ & $13,958 \pm 278^{* * *}$ \\
Serine & $3,669 \pm 327$ & $10,277 \pm 416^{* * *}$ \\
Glutamine & $1,296 \pm 2881$ & $7,818 \pm 943^{*}$ \\
Histidine & $2,054 \pm 495$ & $4,314 \pm 241^{* *}$ \\
Glycine & $2,160 \pm 610$ & $6,760 \pm 675^{* * *}$ \\
Threonine & $3,975 \pm 553$ & $11,500 \pm 544^{* * *}$ \\
Citrulline & $-894 \pm 152$ & $-273 \pm 136^{* *}$ \\
Arginine & $6,248 \pm 517$ & $17,924 \pm 669^{* * *}$ \\
Alanine & $32,396 \pm 2,585$ & $41,833 \pm 2,408^{* *}$ \\
Taurine & $307 \pm 120$ & $297 \pm 72$ \\
Alpha-aminobutyric acid & $122 \pm 78$ & $443 \pm 100^{*}$ \\
Tyrosine & $2,439 \pm 322$ & $11,091 \pm 509^{* * *}$ \\
Valine & $5,696 \pm 786$ & $22,855 \pm 870^{* * *}$ \\
Methionine & $-785 \pm 367$ & $954 \pm 233^{* *}$ \\
Isoleucine & $5,143 \pm 326$ & $18,154 \pm 450^{* * *}$ \\
Phenylalanine & $2,984 \pm 236$ & $8,098 \pm 285^{* * *}$ \\
Tryptophan & $253 \pm 254$ & $2,571 \pm 197^{* * *}$ \\
Leucine & $4,948 \pm 477$ & $21,071 \pm 1,393^{* * *}$ \\
Ornithine & $2,978 \pm 196$ & $7,918 \pm 411^{* * *}$ \\
Lysine & $8,812 \pm 1,068$ & $22,530 \pm 922^{* * *}$ \\
Branched-chain amino acids & $1,5787 \pm 1,492$ & $62,081 \pm 2,476^{* * *}$ \\
Sum amino acids & $89,695 \pm 10,998$ & $233,355 \pm 8,463^{* * *}$ \\
Urea & $-30 \pm 15$ & $118 \pm 15^{* * *}$ \\
\hline & & \\
\hline
\end{tabular}

Values are mean values + SEM, ANOVA repeated measures

${ }^{*} P<0.05,{ }^{* *} P<0.01,{ }^{* * *} P<0.001$

increased at 40,60 , and 80 min after a breakfast with $25 \%$ of energy from soyprotein than after a breakfast with $10 \%$ of energy from soyprotein $(P<0.001$, $P<0.001$ and $P<0.01$ respectively, Fig. 5).

The AUC of the urea response was more increased after a breakfast with $25 \%$ of energy from protein 


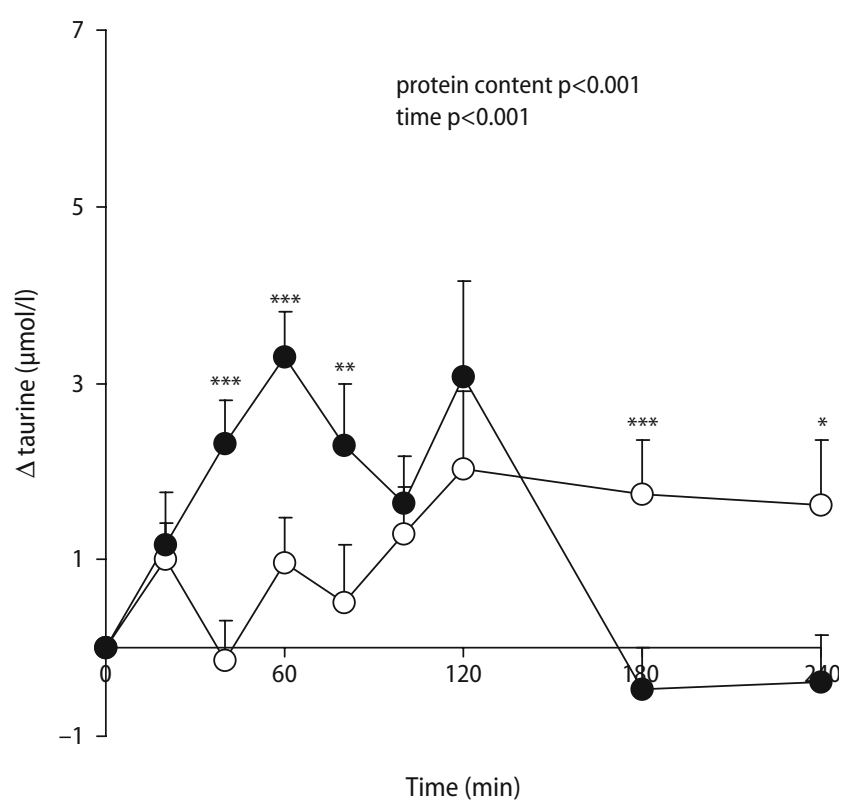

Fig. 5 Changes in taurine concentrations $(\mu \mathrm{mol} / \mathrm{l})$ after a soy breakfast given as a custard with either $10 \mathrm{En} \%$ or $25 \mathrm{En} \%$ from protein expressed as delta compared to baseline in 25 subjects (men and women). Values are mean values + SEM. Open circle 10\% of energy from soyprotein, filled circle $25 \%$ of energy from soyprotein. ANOVA repeated measures showed a protein content $\times$ time interaction effect $(P<0.001)$ and an effect of time $(P<0.001)$ on taurine concentrations; analysis per time point showed a difference in taurine concentrations at $40\left(^{* * *} P<0.001\right), 60\left({ }^{* * *} P<0.001\right)$, $\left.100{ }^{* *} P<0.01\right), 180(* * *<0.001)$ and $240 \mathrm{~min}\left({ }^{*} P<0.05\right)$

than after a breakfast with $10 \%$ of energy from protein $(P<0.001$, Table 2$)$.

\section{Energy intake}

The sensitive moment in time to determine EI in the second set of experiments was based upon the differences in glucose and insulin responses, still being present at $180 \mathrm{~min}$ after breakfast, therefore this moment was chosen to offer lunch.

Energy intake at lunch was $3,098 \pm 286$ and $3,212 \pm 280 \mathrm{~kJ}$ after the breakfast with 10 and $25 \%$ of energy from protein, respectively (ns).

\section{Discussion}

Satiety ratings were higher after a breakfast with $25 \%$ of energy from soyprotein compared with a breakfast with $10 \%$ of energy from soyprotein. The iso-energetic breakfasts contained $20 \%$ of the individual's total daily energy requirements and were of the same color, viscosity, and did not differ significantly in taste.

There may be two different reasons for the observed difference in satiety. The increased satiety after the breakfast with $25 \%$ of energy from soyprotein coincided with an increased insulin response. Insulin is a metabolic satiety signal $[26,32]$ and may explain the increased perceived satiety.

The satiating properties of soyprotein also showed to be dependent on specific amino acid responses. A positive relationship was observed between satiety or hunger suppression and the concentration of the amino acid taurine. Due to the different pattern of taurine concentrations over time, the AUC of the taurine response was not significantly different between the two breakfasts. After a breakfast with $25 \%$ of energy from soyprotein, taurine concentrations increased more than after a breakfast with $10 \%$ of energy from soyprotein. However, after $120 \mathrm{~min}$ taurine concentrations decreased to levels below baseline after a breakfast with $25 \%$ of energy from soyprotein whereas taurine concentrations remained slightly elevated after a breakfast with $10 \%$ of energy from soyprotein. Therefore, there was no difference in taurine response expressed as AUC over $4 \mathrm{~h}$ compared with the breakfast with $10 \%$ of energy from soyprotein. Nevertheless, in those subjects with an increased AUC of taurine an increased satiety and an increased hunger suppression was observed.

Plant proteins do not contain taurine [11], however, it can be synthesized from cysteine in the liver [20]. Since soyprotein is rich in cysteine, this may have been the source of the elevated taurine concentrations [9]. The liver readily synthesizes taurine when cysteine supply is adequate. It is formed via sequential actions of cysteine dioxygenase (CDO) which gives rise to cysteinesulfinate and cysteinesulfinate decarboxylase (CSD). Cysteinesulfinate is then decarboxylated by CSD to hypotaurine which is further oxidized to taurine [19]. Healthy obese subjects were found to have lower taurine concentrations compared with non-obese age- and sex-matched healthy control subjects [10]. Moreover, taurine ingestion has been shown to decrease body weight in hyperglycemic obese mice after a 5\% taurine diet for 10-14 weeks [6]. Furthermore, intake of $3 \mathrm{~g}$ taurine per day for 7 weeks reduced body weight significantly compared with placebo in a group of overweight and obese human subjects [34]. In addition, taurine has also been shown to depress food intake in mice [23]. The present study for the first time showed a direct relation between satiety and/or hunger suppression and taurine concentrations in humans. Sea foods are rich in taurine [11], the satiating effects of fish observed by Uhe et al [24] may be explained by the increased taurine concentrations. Thus, in addition to the literature the present study shows that an increased taurine concentration leads to increased feelings of satiety and suppressed hunger. To summarize, the increased satiety observed after the breakfast with $25 \%$ of energy from soyprotein may be caused by both 
increased insulin and taurine concentrations that were associated with satiety.

Despite the increased satiety after the breakfast with $25 \%$ of energy from soyprotein and the assessment of the sensitive moment in time, we observed no difference in ad lib EI at lunch between a breakfast with $25 \%$ of energy from soyprotein versus a breakfast with $10 \%$ of energy from soyprotein. Also no differences were present between a breakfast with 25 or $10 \%$ of energy from soyprotein with respect to the orexigenic and anorexigenic hormones ghrelin and GLP-1. Soyprotein thus does not contain the specific amino acids that trigger the secretion of these orexigenic and anorexigenic hormones considerably.

To summarize, a breakfast with $25 \%$ of energy from soyprotein was more satiating than a breakfast with $10 \%$ of energy from soyprotein, related to taurine concentrations. Insulin response after the breakfast with $25 \%$ of energy from soy was increased, whereas there were no differences in GLP-1 or ghrelin responses. In conclusion, a high soyprotein breakfast was more satiating than a normal soyprotein breakfast related to elevated taurine and insulin concentrations.

Acknowledgments M. A. B. Veldhorst, A. G. Nieuwenhuizen, A. Hochstenbach-Waelen, K. R. Westerterp, M. P. K. J. Engelen, R.-J. M. Brummer, N. E. P. Deutz, and M. S. Westerterp-Plantenga designed the study. M. A. B. Veldhorst and A. Hochstenbach-Waelen collected and analyzed the data. M. A. B. Veldhorst wrote the manuscript and A. G. Nieuwenhuizen, K. R. Westerterp, M. P. K. J. Engelen, N. E. P. Deutz, and M. S. Westerterp-Plantenga contributed to interpretation of the data and reviewed the manuscript. The study was executed under supervision of A. G. Nieuwenhuizen, K. R. Westerterp, and M. S. Westerterp-Plantenga.

Conflict of interest None of the authors had a personal or financial conflict of interest.

\section{References}

1. Adam TC, Westerterp-Plantenga MS (2005) Nutrient-stimulated GLP-1 release in normal-weight men and women. Horm Metab Res 37:111-117

2. Anderson GH, Tecimer SN, Shah D, Zafar TA (2004) Protein source, quantity, and time of consumption determine the effect of proteins on shortterm food intake in young men. J Nutr 134:3011-3015

3. Bertenshaw EJ, Lluch A, Yeomans MR (2008) Satiating effects of protein but not carbohydrate consumed in a between-meal beverage context. Physiol Behav 93:427-436

4. Clifton PM, Keogh JB, Noakes M (2008) Long-term effects of a high-protein weight-loss diet. Am J Clin Nutr 87:2329

5. Crovetti R, Porrini M, Santangelo A, Testolin G (1998) The influence of thermic effect of food on satiety. Eur J Clin Nutr 52:482-488

6. Fujihira E, Takahashi $H$, Nakazawa $M$ (1970) Effect of long-term feeding of taurine in hereditary hyperglycemic obese mice. Chem Pharm Bull (Tokyo) 18:1636-1642

7. Halton TL, Hu FB (2004) The effects of high protein diets on thermogenesis, satiety and weight loss: a critical review. J Am Coll Nutr 23:373-385

8. Harris JA, Benedict FG (1919) A biometric study of basal metabolism in man

9. Ishihara K, Fukuchi Y, Mizunoya W, Mita Y, Fukuya Y, Fushiki T, Yasumoto K (2003) Amino acid composition of soybean protein increased postprandial carbohydrate oxidation in diabetic mice. Biosci Biotechnol Biochem 67:2505-2511

10. Jeevanandam M, Ramias L, Schiller WR (1991) Altered plasma free amino acid levels in obese traumatized man. Metabolism 40:385-390

11. Laidlaw SA, Grosvenor M, Kopple JD (1990) The taurine content of common foodstuffs. JPEN J Parenter Enter Nutr 14:183-188

12. Lejeune MP, Kovacs EM, WesterterpPlantenga MS (2005) Additional protein intake limits weight regain after weight loss in humans. Br J Nutr 93:281-289

13. Munro HN (1976) Second Boyd Orr Memorial Lecture. Regulation of body protein metabolism in relation to diet. Proc Nutr Soc 35:297-308

14. Pi-Sunyer FX (1993) Medical hazards of obesity. Ann Intern Med 119:655660

15. Seidell JC (1995) Obesity in Europe. Obes Res 3(Suppl 2):89s-93s

16. Senn S (2006) Cross-over trials in Statistics in Medicine: the first '25' years. Stat Med 25:3430-3442

17. Skov AR, Toubro S, Ronn B, Holm L, Astrup A (1999) Randomized trial on protein vs carbohydrate in ad libitum fat reduced diet for the treatment of obesity. Int J Obes Relat Metab Disord 23:528-536

18. Spaaij CJ, Pijls LT (2004) New dietary reference intakes in the Netherlands for energy, proteins, fats and digestible carbohydrates. Eur J Clin Nutr 58:191194
19. Stipanuk MH (2004) Role of the liver in regulation of body cysteine and taurine levels: a brief review. Neurochem Res 29:105-110

20. Stipanuk MH, Dominy JE Jr, Lee JI, Coloso RM (2006) Mammalian cysteine metabolism: new insights into regulation of cysteine metabolism. J Nutr 136:1652S-1659S

21. Stubbs RJ, Hughes DA, Johnstone AM Rowley E, Reid C, Elia M, Stratton R, Delargy H, King N, Blundell JE (2000) The use of visual analogue scales to assess motivation to eat in human subjects: a review of their reliability and validity with an evaluation of new hand-held computerized systems for temporal tracking of appetite ratings. Br J Nutr 84:405-415

22. Stunkard AJ, Messick S (1985) The three-factor eating questionnaire to measure dietary restraint, disinhibition and hunger. J Psychosom Res 29:71-83

23. Thut PD, Hruska RE, Huxtable RJ, Bressler R (1976) Taurine. Huxtable RJ, Barbeau A (eds) pp 357-364

24. Uhe AM, Collier GR, O'Dea K (1992) A comparison of the effects of beef, chicken and fish protein on satiety and amino acid profiles in lean male subjects. J Nutr 122:467-472

25. van Eijk HM, Rooyakkers DR, Deutz NE (1993) Rapid routine determination of amino acids in plasma by high-performance liquid chromatography with a 2-3 microns Spherisorb ODS II column. J Chromatogr 620:143-148

26. VanderWeele DA (1994) Insulin is a prandial satiety hormone. Physiol Behav 56:619-622 
27. Velasquez MT, Bhathena SJ (2007) Role of dietary soy protein in obesity. Int J Med Sci 4:72-82

28. Weigle DS, Breen PA, Matthys CC, Callahan HS, Meeuws KE, Burden VR, Purnell JQ (2005) A high-protein diet induces sustained reductions in appetite, ad libitum caloric intake, and body weight despite compensatory changes in diurnal plasma leptin and ghrelin concentrations. Am J Clin Nutr 82:4148

29. Westerterp-Plantenga MS, LuscombeMarsh N, Lejeune MP, Diepvens K, Nieuwenhuizen A, Engelen MP, Deutz NE, Azzout-Marniche D, Tome D, Westerterp KR (2006) Dietary protein, metabolism, and body-weight regulation: dose-response effects. Int J Obes (Lond) 30(Suppl 3):S16-S23

30. Westerterp-Plantenga MS, Westerterp KR, Rubbens M, Verwegen CR, Richelet JP, Gardette B (1999) Appetite at "high altitude" [Operation Everest III (Comex-'97)]: a simulated ascent of Mount Everest. J Appl Physiol 87:391399

31. Westerterp KR, Kester AD (2003) Physical activity in confined conditions as an indicator of free-living physical activity. Obes Res 11:865-868

32. Woods SC, Chavez M, Park CR, Riedy C, Kaiyala K, Richardson RD, Figlewicz DP, Schwartz MW, Porte D Jr, Seeley RJ
(1996) The evaluation of insulin as a metabolic signal influencing behavior via the brain. Neurosci Biobehav Rev 20:139-144

33. Young VR (1991) Soy protein in relation to human protein and amino acid nutrition. J Am Diet Assoc 91:828-835

34. Zhang M, Bi LF, Fang JH, Su XL, Da GL, Kuwamori T, Kagamimori S (2004) Beneficial effects of taurine on serum lipids in overweight or obese non-diabetic subjects. Amino Acids 26:267-271 